suggesting that modern stressors such as climate variability (Long et al., 2010; Magnuson et al., 1997), invasive species (Lougheed and Stevenson 2004; Steinman et al., 2008) and further land use alterations (Ray and Pijanowski 2010; Pijanowski et al., 2007; Tang et al., 2005) whose influence remain uncertain, are likely to influence system recovery.

\section{Recovery challenges and recommendations}

Efforts to manage the watershed have reduced the loading of metals and nutrients, improving the ecological health of Muskegon Lake as evidenced by geochemistry and diatom biostratigraphy. The current geochemical conditions demonstrate significant recovery from high concentrations of anthropogenic elements and the fossil diatom record from this core suggests that efforts to reduce nutrient loading have been successful. Despite improvements, these data indicate that the system is still changing in response to human impacts at the regional watershed scale, suggesting that management strategies also need to target non-point source inputs. As such, it is recommended that modern remediation targets consider the legacy and overprint of multiple stressors, as well as be aware of emerging stressors that could further alter ecological dynamics in the larger Great Lakes Region.

\section{Acknowledgements}

We thank the Great Lakes Fisheries Trust for funding this research, and the Aqueous and Environmental Geochemistry Laboratory at MSU for providing financial and technical support. Glen Schmitt and the Michigan Department of Environmental Quality are recognized for help in the field. Special thanks to Dr. Nadja Ognjano-
va-Rumenova for diatom taxonomical processing and identification.

\section{References}

Alexander, J., 2006: The Muskegon: The Majesty and Tragedy of Michigan's Rarest River, Michigan State University Press, 1-214 pp.

Freedman, P., Canale, R. and Auer, M., 1979: The impact of wastewater diversion spray irrigation on water quality in Muskegon County lakes, U.S. Environmental Protection Agency, Washington, D.C EPA 905/9-79-006-A.

Long, D.T, Parsons, M.J., Yansa, C.H., Yohn, S.S., Mclean, C.E. and Vannier, R.G., 2010: Assessing the response of watersheds to catastrophic (logging) and possible secular (global temperature change) perturbations using sediment-chemical chronologies, Applied Geochemistry, 25: 143-158.

Pijanowski, B., Ray, D.K., Kendall, A.D., Duckles, J.M. and Hyndman, D.W. 2007: Using backcast landuse change and groundwater traveltime models to generate land-use legacy maps for watershed management, Ecology and Society, 12(2): 25.

Steinman, A., Ogdahl, M., Rediske, R., Ruetz, C.R. III, Biddanda, B.A. and Nemeth, L., 2008: Current Status and Trends in Muskegon Lake, Michigan, Journal of Great Lakes Research, 34: 169-188.

For full references please consult:

http://www.pages-igbp.org/products/newsletters/ref2011_2.pdf

\title{
Landslides in São Paulo, Brazil: An integrated historical
} perspective

Lucí Hidalgo Nunes

Department of Geography, State University of Campinas, Brazil; luci@ige.unicamp.br

\begin{abstract}
The growing severity of floods and landslides in the state of São Paulo, Brazil, is related to rapid environmental changes, such as urbanization, deforestation and settlement in hazardous areas, rather than to natural events, and unless more sustainable land-use practices are adopted the impact of these (un)natural disasters might become more severe.
\end{abstract}

\section{The Problem}

The Emergency Events Database (EMDAT, www.emdat.be/), an international database of disasters maintained by the Centre for Research on the Epidemiology of Disasters (CRED), states that during the period from 1948 to 2010 Brazil was hit by 146 disasters related to precipitation (storms, floods and mass movements) that caused 8627 deaths and affected nearly 3 million people. Approximately $75 \%$ of these calamitous episodes have occurred in the last three decades (1980 to 2010) (EM-DAT, 2010). These figures are probably underestimated (Marcelino et al., 2006; Nunes, 2009) but are consistent with other studies that have demonstrated an upward trend in the severity of disasters triggered by precipitation. It has drawn attention to the question of how strongly this dramatic trend is connected to societal changes, with an ever-growing vulnerability to weather and climate episodes (Kunkel et al., 1999; Changnon et al., 2000;

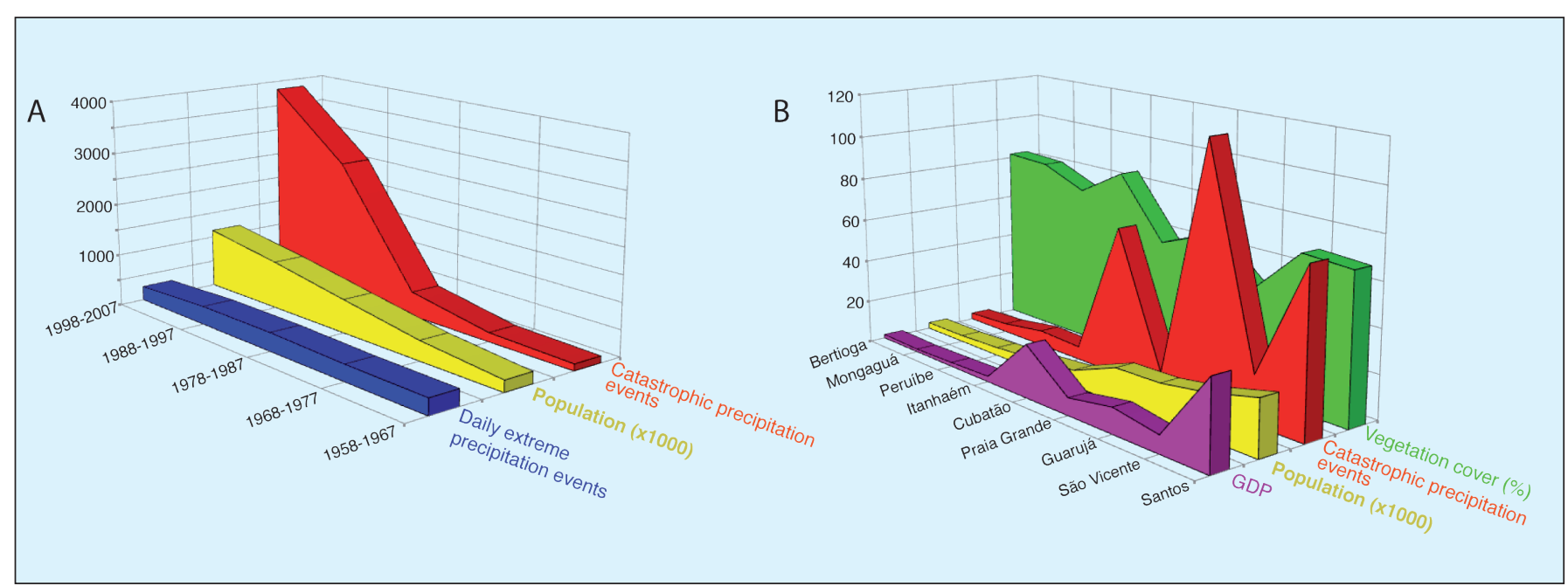

Figure 1: A) Number of catastrophic events caused by precipitation (red) compared with population (yellow) and daily extreme precipitation episodes (blue) in Campinas, Brazil, for 5 decades (1958-1967 to 1998-2007). B) Comparison between Gross Domestic Product (GDP, purple, 2009), population (yellow, 2010), percentage of remaining vegetation (green, 2010) and survey (partially completed) of catastrophic events triggered by precipitation (red) from 1928 to 2009 , for 9 municipalities of the Metropolitan Region of Baixada São Paulo, Brazil. Higher number of catastrophic events is related to higher deforestation, and lower GDP to lower rates of deforestation. 
Kesavan and Swaminathan, 2006; Araki and Nunes, 2008).

During the second half of the $20^{\text {th }}$ century, urban population increased steadily in Brazil and according to the census of 2010 (IBGE, www.censo2010.ibge.gov.br/), $84.3 \%$ of Brazilians live in urban centers. The unplanned growth of cities has led to an increasing inability to house this growing population and to provide adequate infrastructure. Poor regulation has led to inappropriate land use transformation in hazard prone areas, higher pressure on natural resources, lack of appropriate waste treatment and sanitation, violence, and other environmental and societal problems. Rapid urban expansion has the potential to adversely affect ecological dynamics, biodiversity and local climate, as well as patterns of local energy and water consumption.

\section{Land use pattern and natural} disasters in the state of São Paulo The impacts of extreme precipitation events are even more acute in the state of São Paulo, where $21.6 \%$ of the Brazilian population is concentrated (95.9\% in urban centers) and which contributes $33.1 \%$ of the national GDP. Three recent assessments of the historical interactions between climate and social change are providing insight into the controls on landslides and flood:

1) Evaluating the consequences of extreme precipitation events between 1958 and 2007 in Campinas $(1,080,999$ inhabitants, census of 2010), Castellano (2010) observed a significant increase in the number of the impacts (e.g., damages to buildings and trees, power cut and traffic chaos) recorded from 129 impacts in the first decade to 3,837 in the last. During the same period, the population increased by $500 \%$, but no changes in the frequency of extreme precipitation events were recorded (Fig. 1A).

2) The urbanization of Bauru $(344,039$ inhabitants, 2010) led to decreased soil infiltration with increased runoff released into the natural drainage network, further leading to gullies and more frequent floods. Comparing daily precipitation events above $10 \mathrm{~mm} /$ day and erosion and floods from 1967 to 1999, Almeida Filho and Coiado (2001) noticed that the rainfall pattern did not change significantly during the whole period. However, $66 \%$ of the episodes occurred between 1984 and 1999, the period of urban population expansion that was not accompanied by urban planning or adequate engineering.

3) The eastern portion of the state, a mountainous region with steep hills at the

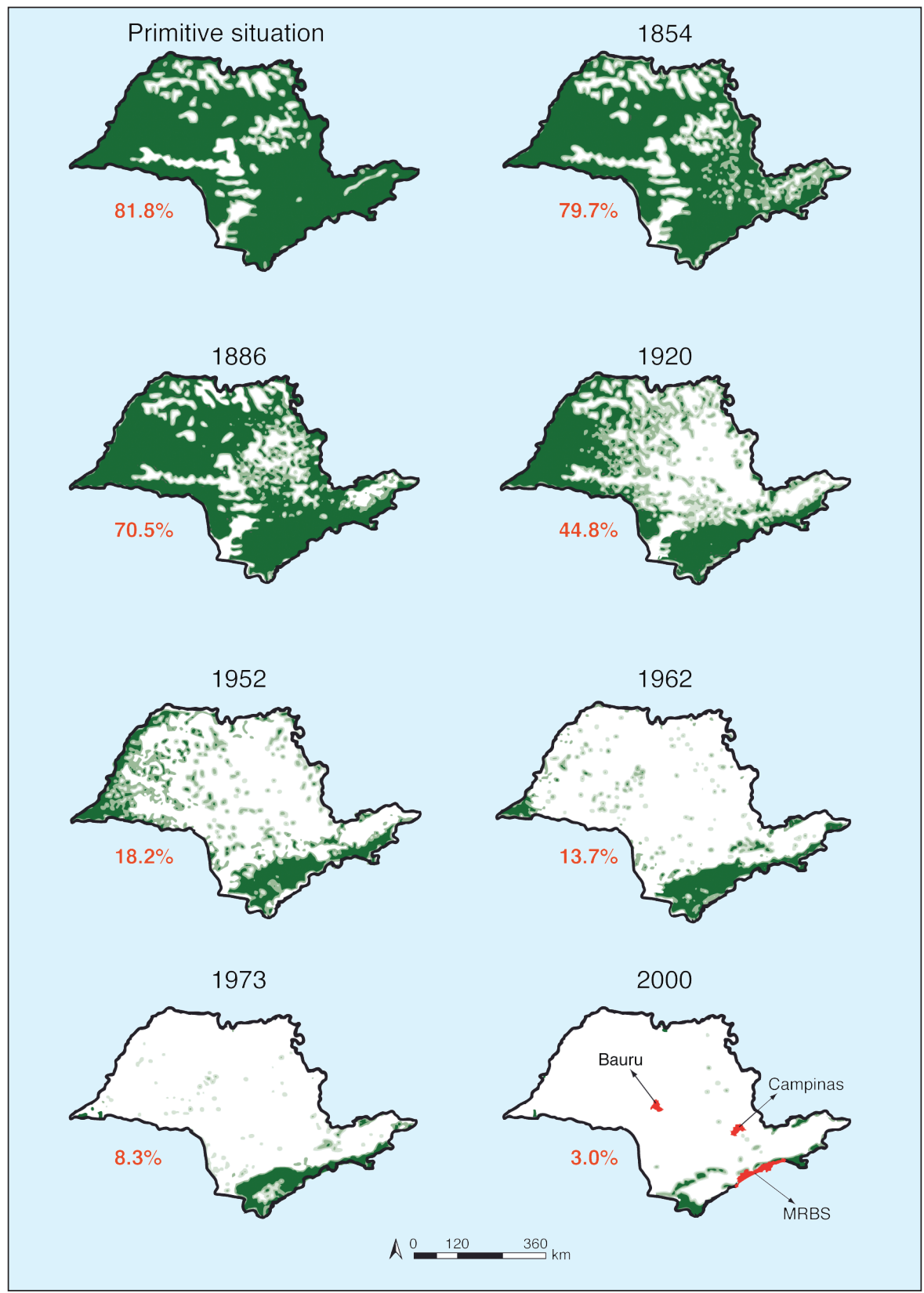

Figure 2: Deforestation of the Atlantic Rainforest in the state of São Paulo from 1854 to 2000. Red numbers indicate the estimation of \% forest cover for each period (from Victor, 1975). Red shaded areas indicate location of study areas discussed in the text. MRBS $=$ Metropolitan Region of Baixada Santista.

base of the coastal Serra do Mar Range, is particularly sensitive to natural disasters, with more than 16,000 people living in areas at risk of landslides, mudslides and floods. Some sectors register very intense precipitation episodes. In Cubatão (108,309 inhabitants, 2010), an industrial complex located in a valley surrounded by the unstable hill slopes of Serra do Mar, summer precipitation intensities reached $1021 \mathrm{~mm}$ in nine days (February 1929) and $712 \mathrm{~mm}$ in two days, (February 1934), as verified by Nunes (2008). In the past few decades Guarujá municipality, an upmarket resort area (290,607 inhabitants, 2010), has experienced an increase in tourism and related activities. This has attracted an influx of workers who largely occupy unstable slopes. As a result, the city has both the highest deforestation rate and highest number of catastrophes triggered by pre- cipitation (floods and landslides) amongst the nine municipalities that are part of the Metropolitan Region of Baixada Santista (MRBS). For the entire area, the correlation between these two variables is -0.85 , significant at $95 \%$. Furthermore, the lowest deforestation rates are found in municipalities that also have the lowest GDP, suggesting that the economic development of the region is based on unsustainable practices (Fig. 1B). It is worth emphasizing that this pattern of occupation, with houses perched on steep slopes and next to rivers, is similar to the alpine district of Rio de Janeiro state, where the heavy rains of January 2011 have caused floods, landslides and mudslides resulting in hundreds of deaths and missing persons as well as major economic losses.

Historical information is also being used to highlight the rapid deforestation 
of the Atlantic Rainforest in recent decades, which is crucial to understanding the recent trends in environmental degradation in São Paulo state. An attempt to reconstruct the forest cover of the state was done by Victor (1975) and Victor et al. (2005) based on reports of pioneers and naturalists, the rise and mobility of population, agriculture expansion and more recently on aerial photo interpretation. It shows that the forest cover of the state was drastically reduced (Fig. 2) by the spread of agriculture and industrialization. The amount of forest cover remaining today corresponds to 2, 8 and $55 \%$ of the original area in Campinas, Bauru and $\mathrm{Cu}$ batão, respectively.

\section{Future Directions}

From the perspectives of both local sustainable development and global change, São Paulo is a "hot spot". There is a great need to break the cycle of destruction and reconstruction linked to catastrophic events. Knowledge of the extent of histori- cal environmental degradation through depletion of resources, such as has occurred in the Atlantic Forest, and a comprehensive evaluation of the frequency and magnitude of floods and landslides are essential to understanding the evolution of natural disasters. Further studies that take into account the characteristics of the river channel network, the sediment yield from these catchments, the landslide scars, and the weathering and soil development must encompass at least decadal timescales in order to provide rates and nature of changes that take place over planning timescales. The evaluation of current economic development strategies, including policies, guidelines and laws, are vitally important to develop strategies that can lead the entire region towards a more sustainable development trajectory. Planning must be constrained by rules that are defined and rooted in long-term and regional to inter-regional analyses of the optimum and sustainable uses of space.

\section{Acknowledgements}

I thank Daniel Henrique Candido, PhD student at UNICAMP for the improvement of the figures, and MsD. Ciro Koiti Matsukuma and Valdir de Cicco, Instituto Florestal, for providing the information on deforestation. I also thank Dr. Francisco Sergio Bernardes Ladeira, UNICAMP and Professor John Dearing, University of Southampton, for valuable suggestions.

\section{References}

Almeida Filho, G.S. and Coiado, E.M., 2001: Processos erosivos lineares associados a eventos pluviosos na área urbana do município de Bauru, SP. Avaliable at: http://www.labogef.iesa.ufg.br/links/ simposio_erosao/articles/T085.pdf

Araki, R. and Nunes, L.H., 2008: Vulnerability associated with precipitation and anthropogenic factors in Guarujá City (São Paulo, Brazil) from 1965 to 2001, Terrae - Geoscience, Geography, Environment, 3(1): 40-45

Castellano, M.S., 2010: Inundações em Campinas (SP) entre 1958 e 2007 : tendências socioespaciais e as ações do poder público, Master Dissertation, IG-UNICAMP, (English Abstract).

Changnon, S.A., Pielke Jr, R.A., Changnon, D., Sylves, R.T. and Pulwarty, R., 2000: Human factors explain the increased losses from weather and climate extremes, Bulletin of the American Meteorological Society, 81: 437-442.

Victor, M.A. de M., Cavalli, A.C., Guillaumon, J.R. and Serra Filho, R. 2005: Cem anos de devastação: revisitada 30 anos depois, Available at http://antoniocavalli.com/cem\%20anos\%20de\%20 devasta\%C3\%A7\%C3\%A30.pdf (English translation).

For full references please consult:

http://www.pages-igbp.org/products/newsletters/ref2011_2.pdf

\title{
Regional wetland response typology: Murray-Darling Basin, Australia
}

\author{
Michael Reid ${ }^{1}$ and Peter Gell ${ }^{2}$ \\ 'University of New England, Australia; mreid24@une.edu.au \\ ${ }^{2}$ University of Ballarat, Australia.
}

\section{Paleoecological records from billabongs (floodplain lakes) in southern Australia can be used to develop ecosystem response models that describe how the underlying hydrology and geomorphology of these aquatic ecosystems control their resilience to anthropogenic stressors.}

\begin{abstract}
Water demands
Lowland floodplain rivers are "hotspots" of biodiversity and productivity. The ecological importance of these environments is particularly substantial in Australian semiarid and arid environments because of the moisture subsidy they provide to riverine ecosystems (Ogden et al., 2007). In Australia's dry climate, these environments have also become extremely important for agriculture, which in turn has led to deterioration in ecosystem function and reduced biodiversity. Competing demands for water by ecological and economic systems has led to an apparently intractable debate over how best to allocate water to support sustainable agriculture and ecosystems. The recent debate over the water allocation prescriptions within the Murray Darling Basin Plan (MDBA, 2010) reveal that the changing condition of floodplain wetlands (billabongs) across the region is not well understood. In order to meet this
\end{abstract}

challenge it is vital that water is used efficiently for both agriculture and to support riverine ecosystems. The second half of this equation presents an immense challenge to scientists and managers because our understanding of riverine ecosystem function is limited by a lack of robust data on benchmark conditions, ecosystem variability, and the drivers and trajectories of change.

\section{Ecosystem histories and complexity}

Data and information needed to reconstruct ecosystem histories can be provided through paleoecological studies of wetlands. Furthermore, for a basin-wide appreciation, a regional integration of paleoecological studies can reveal the extent and timing of changes to provide broad insights into the ecological cost of the diversion of river flows to support irrigated agriculture.
While factors, such as invasive species and land use, can influence ecosystem structure and function (Roberts et al., 1995; Robertson and Rowling, 2000), floodplain aquatic ecosystems are principally driven by hydrology (Walker, 1985; Bunn et al., 2006). Thus, hydrological changes experienced by billabongs are likely to have a substantial influence on their ecology. However, while the hydrology of a river as a whole is primarily driven by extrinsic factors, the hydrology of individual billabongs is also strongly influenced by intrinsic factors, such as local adjustments in channel morphology, the deposition of sediments in secondary channels linking billabongs to the main channel, and the infilling of the billabongs themselves. Thus individual billabongs may reflect any number of environmental changes operating across a range of spatial and temporal scales. The distinction between local and regional drivers of change can 